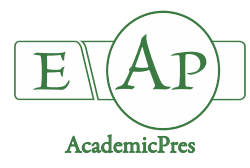

\title{
Validation of Gender Specific CAPS Marker in Turkish Fig (Ficus carica L.) Collection and F1 Progenies
}

\author{
Hatice IKTEN*, Yeliz YILMAZ \\ Akdeniz University, Faculty of Agriculture, Department of Agricultural Biotechnology, 07070, Antalya, \\ Turkey; haticeikten@akdeniz.edu.tr ("${ }^{*}$ correspondingauthor);yelizyilmaz@windowslive.com
}

\begin{abstract}
In most dioecious plants, distinguishing male and female progenies is not possible until flowering or fruiting stage. The fig (Ficus carica L.) is such a plant where distinguishing male and female plants at the seedling stage can accelerate fig-breeding programs. An orthologue of RAN1 loci was reported to be associated with sex determination in fig (Mori et al., 2017). The objective of this study is to validate this locus on Turkish fig germplasm collection and F1 population obtained from a cross between female genotypes 'Bursa Siyahi' and male genotype 'Ak Ilek'. A total of 144 genotypes from germplasm collection and 115 F1 individuals were tested with CAPS (cleaved amplified polymorphic sequences) marker following the Mori et al. (2017). The loci produced a $315 \mathrm{bp}$ amplification product from all genotypes. PciI digestion of PCR products resulted in $100 \%$ concordance between phenotypes and molecular tests. On the other hand, HpyCH4IV enzyme digestion of 8 female genotypes resulted in false negatives among the tested materials. Therefore, despite overall results show that the locus is suitable for gender selection of plants at the seedling stage in the breeding programs, care should be taken when $H p y C H 4 I V$ enzyme is to be employed for CAPS assay.
\end{abstract}

Keywords: female plants; fig breeding; male plants; marker assisted selection; sex determination

\section{Introduction}

The fig (Ficus carica L.) is an economically important crop in the world especially in countries bordering the Mediterranean Sea, Red Sea, Arabian Sea and U.S.A (Storey, 1975). The world fig production is around 1.13 million tons (FAOSTAT 2013). Turkey ranks the first three among fig producing countries. As in most dioecious plants, only the female fig plants are commercially valued for production and it is not possible to distinguish the male and female trees until they pass through the juvenile period and produce fruits. Furthermore, fig flowers are located inside of the syconia, and produce edible fruits if they are pollinated by special fig wasps (Blastophaga psenes) (Condit, 1969). Hence, breeding efforts are hampered by highly outcrossing feature, dioecy, and long juvenile period of plant development. Therefore, distinguishing male and female plants at the seedling stage could accelerate breeding studies by reducing the labor, time and other expenses in breeding programs (Storey, 1975). Different methods have been employed for sex determination in deciduous plant species (Zheng and Zhu, 2006; Mao et al., 2018). In fig, phenolic compounds, leaf properties and number of stomas in male and female plants were compared and despite presence of higher amounts of phenolic compounds in male genotypes, further detailed studies were recommended (Misirlı et al., 1998a, 1998b). Morphological and biochemical markers can vary depending on external factors and may not be fully reliable. On the other hand, molecular markers are easy to practice, more reliable, not effected by environmental conditions and plant growth stage (Francia et al., 2005) and marker assisted selection has become an important tool in selection of progenies carrying the desired characters (Sestras et al., 2009).

The gender specific molecular markers have been developed for some dioecious fruit species such as Pistacia vera L. (Hormaza et al., 1994; Yakubov et al., 2005; Kafkas et al., 2015), Carica papaya L. (Deputy et al., 2002; Urasaki et al., 2002), Phoenix dactylifera L. (Maryam et al., 2016 ), Actinidia chinensis (Zhang et al., 2015), Simmondsia chinensis (Agrawal et al. (2007); Ince and Karaca (2011); Heikrujam et al. (2014) and Ficus carica (Mori et al., 2017). In Ficus fulva, a male specific AFLP marker has been developed by Parrish et al. (2004). After converting this AFLP marker to SCAR marker, the polymorphism between male and female genotypes has been lost (Parrish $e t$ 
868

al., 2004). An association mapping study was carried on for gender specific molecular marker in Ficus carica and five markers explained the $77 \%$ of the total variation between male and female genotypes (Mutlu et al., 2008). Recently, Mori et al. (2017) found a gender specific locus in Ficus carica based on a GWAS analysis of 122 genotypes by using 16,124 SNPs derived from RADseq protocol. The locus was converted to a CAPS assay and PCR products were digested with PciI and $H p y C H 4 I V$ enzymes for distinguishing of male and female genotypes. The aim of the present study was to validate previously developed sex-linked CAPS markers by Mori et al. (2017) on the male and female plants obtained from fig genetic resources collection of Turkish origin and further test MAS applicability of locus on F1 population.

\section{Materials and Methods}

\section{Plantmaterial}

Fifty-four male and 90 female genotypes from Turkish fig germplasm core collection (Supplementary Table 1) and $115 \mathrm{~F} 1$ plants obtained from a cross between female parent 'Bursa Siyahi' and male parent 'Ak Ilek' were used as study material. All study material was kindly provided by Ministry of Food, Agriculture and Livestock, Fig Research Institute, Aydin, Turkey. Sex phenotype data for germplasm collection has been collected by the same Institute since 1970 s.

\section{DNA extraction and molecular diagnostic assay}

DNA was extracted from fresh or frozen leaves by following the modified CTAB protocol (Doyle and Doyle, 1990). After DNA extraction, the samples were loaded and run on $1 \%$ TAE agarose gel for quality control. A primer pair (Fig FM_f: 5' CAATACCAAAATGATATGCACGA-3', and Fig FM_r: 5'-TGGCATATACAGTGAGAT-GGATG-3') developed by Mori et al. (2017) were utilized for amplification of sex associated CAPS loci: PCR reaction was optimized for a total volume of $15 \mu \mathrm{l}$ PCR mix containing $1.5 \mu \mathrm{l} 10 \mathrm{x}$ reaction buffer, $0.2 \mathrm{mM}$ dNTPs, 1.5 $\mathrm{mM} \mathrm{MgCl}$, 10 pmol of each primer pair, 0.8 unit of $\mathrm{Taq}$ DNA polymerase, and 25-30 ng DNA. Thermocycler condition was as follows: 35 cycles of denaturation at $94^{\circ} \mathrm{C}$ for $30 \mathrm{~s}$, annealing at $55^{\circ} \mathrm{C}$ for $30 \mathrm{~s}$ and extension at $72{ }^{\circ} \mathrm{C}$ for $30 \mathrm{~s}$. The program was preceded by a denaturing step at $94^{\circ} \mathrm{C}$ for $3 \mathrm{~min}$. and ended with an extension step at $72^{\circ} \mathrm{C}$ for $5 \mathrm{~min}$. After amplification, half of each PCR products were digested with PciI and $H p y C H 4 I V$ restriction enzymes in separate tubes. In each digestion reaction, a total volume of $10 \mu \mathrm{l}$ digestion mix set up included $1 \mu \mathrm{l} 10 \mathrm{x}$ Buffer, $7 \mu \mathrm{l}$ PCR product, $1 \mathrm{U}$ enzyme and $1 \mu \mathrm{H} 2 \mathrm{O}$. Both digestion reactions incubated at $37^{\circ} \mathrm{C}$ for 2 hours before loading and running on $2 \%$ TAE agarose gel for visualization and documentation.

\section{Results and Discussion}

An orthologue of $R A N 1$ locus was reported to be associated with sex determination in fig (Mori et al., 2017).
In current study, this locus was tested on the sex- types known 54 male and 90 female plants from Turkish fig germplasm collection as well as a segregating $\mathrm{F} 1$ population. Locus specific primer pair amplified a 315 bp fragments in both female and male plants from whole collection.

\section{Digestion with PciI enzyme}

After the digestion of PCR product with PciI enzyme, three fragments were clearly visible $(242,186$ and $73 \mathrm{bp}$ products) as revealed by Mori et al. (2017). One of the digested fragments $(242 \mathrm{bp})$ representing female allele (CGT and TGT) was present in all female plants. On the other hand, $186 \mathrm{bp}$ fragment (CAT allele) appeared in all 54 male plants, but it was absent in all female genotypes. Furthermore, male genotypes had 242 bp fragments (CGT and TGT) as they are all heterozygous for gender as reported by Storey (1975). Digestion product of 73 bp fragment was present in both male and female genotypes and not relevant to sex determination (Fig. 1). Of the 144 genotypes tested from collection, marker predictions were accurate for both male and female genotypes. The results of the molecular analysis with PciI enzyme were entirely correlated with phenotypic observations (Supplementary Table 1) and parallel to the results from Mori et al. (2017).

\section{Digestion with HpyCH4IV enzyme}

Digestion of PCR amplicons with HpyCH4IV enzyme resulted in up to three fragments depending on gender as described by Mori et al. (2017). PCR amplicons from female allele CGT were completely cut with $\mathrm{HpyCH} 4 \mathrm{IV}$ enzyme producing 186 and 129 bp fragments (Fig. 2), whereas male allele CAT was not cut with $\mathrm{HpyCH} 4 \mathrm{IV}$ enzyme remaining as intact $315 \mathrm{bp}$ PCR amplicon. Therefore, gel profiles from male genotypes appeared as three fragments $(315,186$ and $129 \mathrm{bp})$ since they are all in heterozygous state (Storey, 1975). Nonetheless, digestion of PCR products from 8 female genotypes with $\mathrm{H}_{p y C H} \mathrm{CH} \mathrm{V}$ enzyme resulted in 315, 186 and 129 bp products, hence appeared as male genotypes. As a result, gel profiles for 8 female genotypes conflicts with gender expectation. In fact, similar contradictory results were also reported for some female genotypes with $\mathrm{HpyCH} 4 \mathrm{IV}$ enzyme digestion (Mori et al., 2017) and most probably results from the fact these female genotypes had TGT female allele along with CGT female allele. Since, enzyme $H p y C H 4 I V$ cannot digest TGT female allele, gel profiles from these 8 female genotypes appeared as males.

\section{Screening of $F 1$ plants at juvenile stage}

One hundred fifteen F1 fig plants along with their parents (female parent, 'Bursa Siyahi' and male parent, 'Ak Ilek') were screened at $R A N 1$ loci. PCR reaction produced a 315 bp fragment from all F1 plants as their parents. Digestion with PciI enzyme showed expected polymorphism profile between male and female parents as explained above. Of the 115 F1 plant tested, 60 of them produced digestion products of $186 \mathrm{bp}$ fragments (CAT allele) and were predicted as male whereas 55 of the genotypes had a digestion product of $242 \mathrm{bp}$ fragments representing female allele (Fig. 3). Storey (1975) indicated 
that a cross between caprifig and fig results in a segregation ratio of 1 male: 1 female in their offspring. Here, we had a similar ratio of 1 male: 0.92 female supporting the reports of Storey (1975). Furthermore, the marker showed $100 \%$ reliable sex diagnosis in male and female plants as indicated by concordance between phenotypic and molecular results.

In fig breeding, one-half of the progeny is useless since the fruits of male genotypes are commercially not valuable (Storey, 1975). Fig seedlings takes five to seven years before bearing fruits, hence breeders had to double the resources for their fig breeding program in early years. For example, Doyle and Ferguson (1998) had to eliminate $50 \%$ of the seedlings, 6 to 7 years after planting. Early sex determination methods make it possible to select male and female plants at the seedling stage (Uragami et al., 2016). Developing reliable and simple molecular markers with high effectiveness is a long and difficult process. For example, a gender specific molecular marker in pistachio developed by Hormaza et al. (1994) from RAPD primers then converted to SCAR by Yakubov et al. (2005) and tested by Kafkas et al. (2015) in a segregating population, and germplasm collection of pistachio. The marker generated false negatives in some female individuals and false positives in some male individuals. Hence, testing and validating the markers developed in other populations increase their reliability for MAS in breeding programs (Ejaz et al., 2015; Javid et al., 2015). Although, we confirmed the high efficiency of $R A N 1$ locus to identify gender in 144 Turkish fig germplasm (Supplementary Table 1) and segregating 115 F1 plants, there is a consideration with the use of HpyCH4IV enzyme. Since a few female genotypes in collection bear TGT alleles in their background, erroneous elimination of offspring is possibility if those females involved in breeding programs. Therefore, molecular test should be performed on parents before beginning crossing efforts if $\mathrm{HpyCH} 4 \mathrm{IV}$ enzyme is to be utilized. Nonetheless, PciI enzyme does not seem to pose any risk for reliable gender determination hence should be preferred. Overall, the study confirms that CAPS assay on RAN1 locus is a reliable way of determining gender in fig offspring and suitable for employing within fig breeding programs.

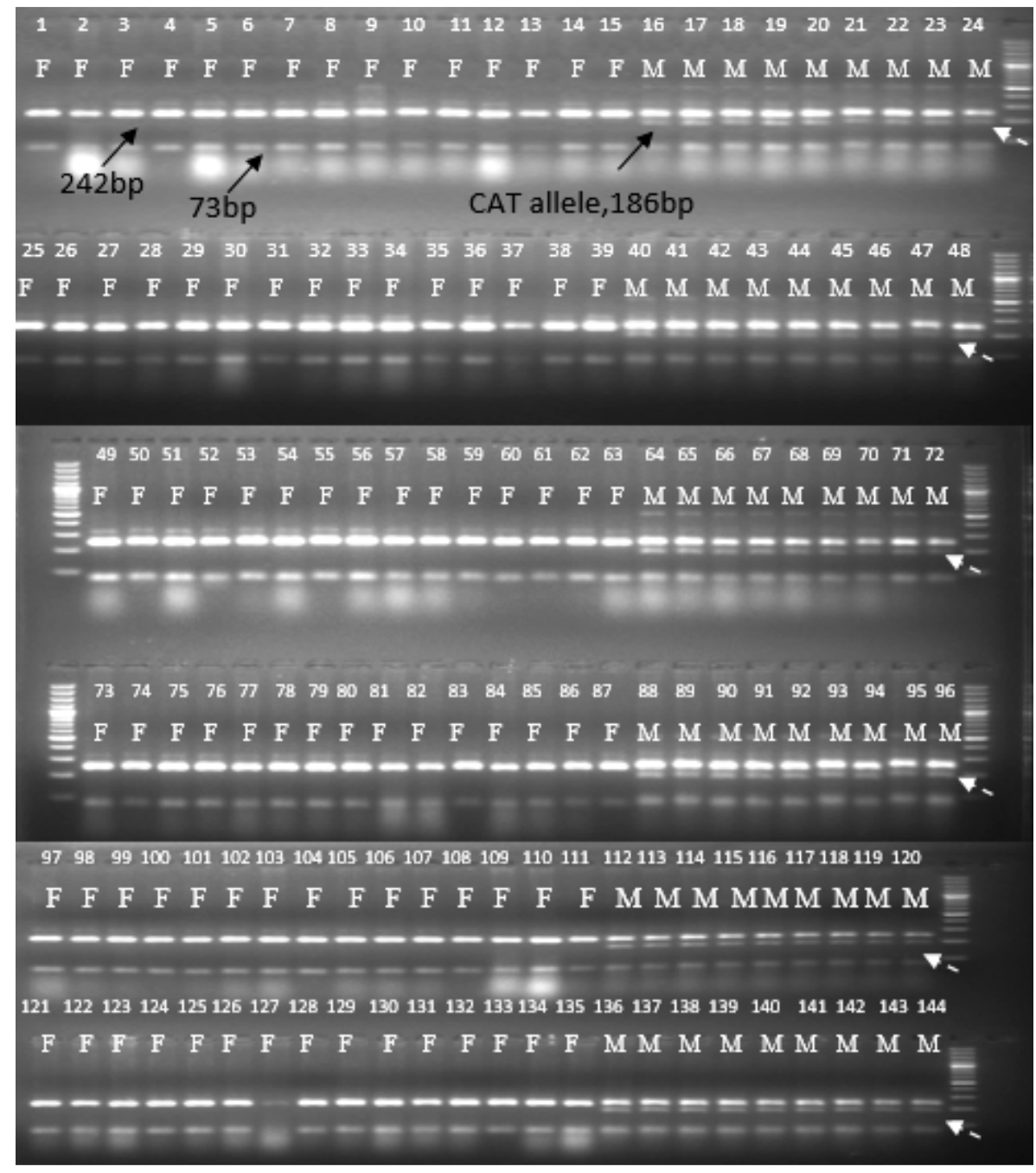

Fig. 1. Analysis of 144 genotypes detecting male and female genotypes using developed CAPS marker by Mori et al. (2017) (digestion with PciI enzyme) 


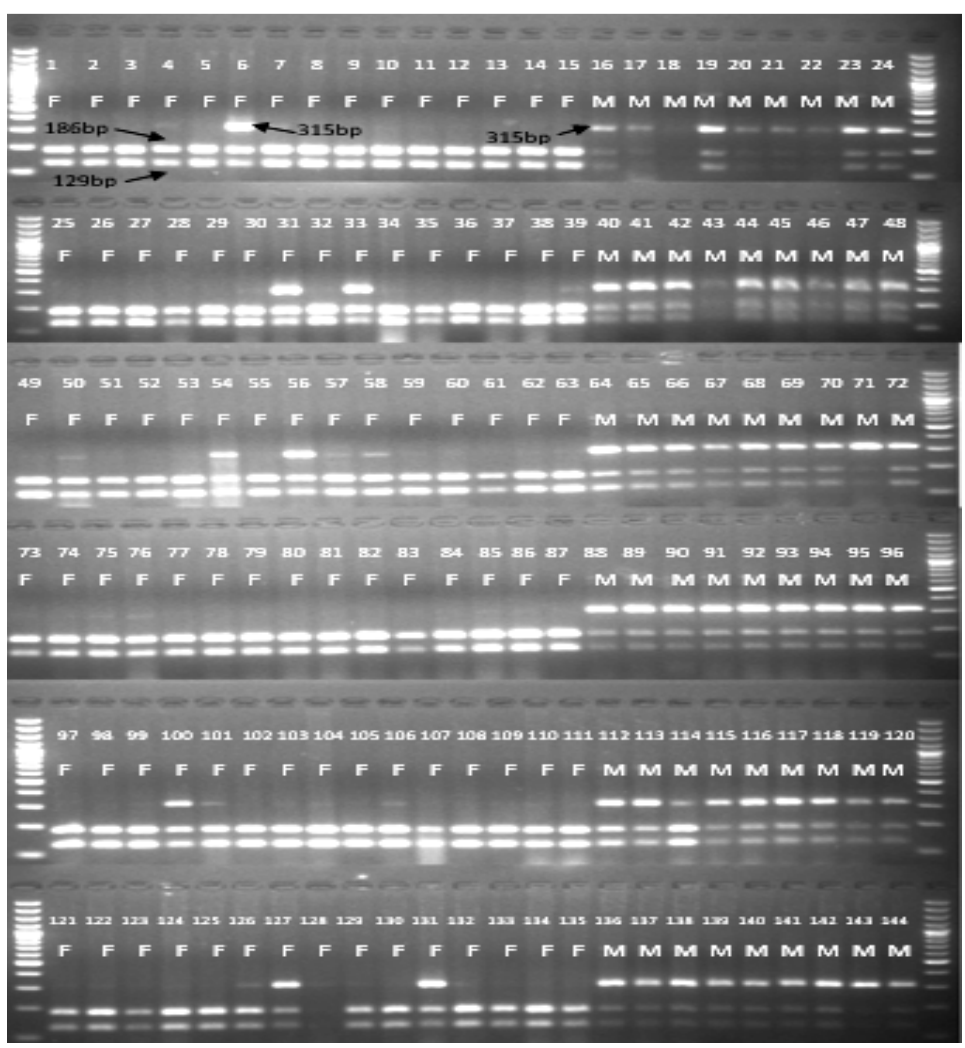

Fig. 2. Analysis of 144 genotypes detecting male and female genotypes using developed CAPS marker by Mori et al. (2017) (digestion with $H p y C H 4 I V$ )

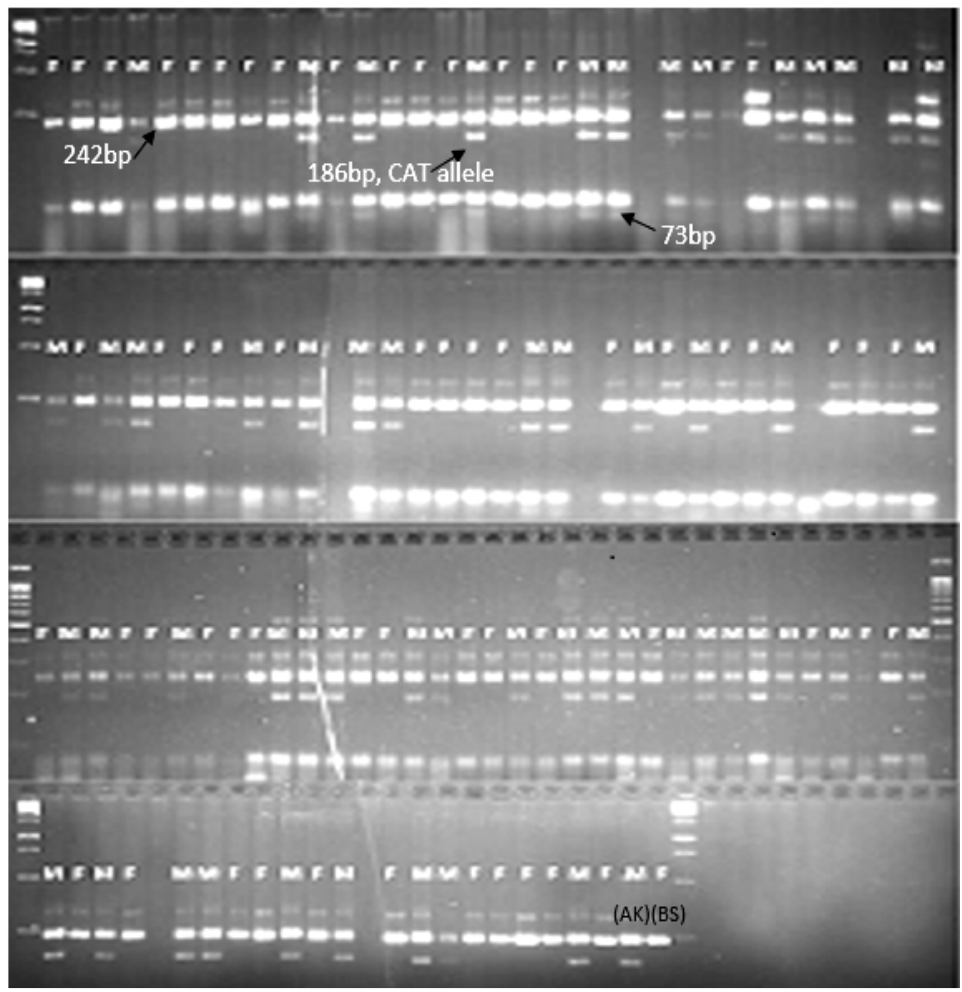

Fig. 3. Analysis of 115 F1 individuals as well as the parental genotypes ('Bursa Siyahi', BS and 'Ak Ilek', AK) detecting male and female genotypes using developed CAPS marker by Mori et al. (2017) (digestion with PciI enzyme) 


\section{Conclusions}

In this study, we screened the fig genotypes for gender determination and report the validation of already developed sex- linked DNA marker in fig genotypes from genetic resources collection plot and F1 population. The marker offers potential to be used for detection of female and male plants in the F1 population, making this marker suitable for employing within the fig-breeding program.

\section{Acknowledgements}

We thank to Akdeniz University Scientific Research Projects Coordination Unit for financial support (grant number: FYL-2017-2633) and Fig Research InstituteAydin, Turkey for research material.

\section{Conflicts of interest}

The authors declare that there are no conflicts of interest related to this article.

\section{References}

Agrawal V, Sharma K, Gupta S, Kumar R, Prasad M (2007). Identification of sex in Simmondsia chinensis (Jojoba) using RAPD markers. Plant Biotechnology Reports 1(4):207-210.

Condit IJ (1969). Ficus: The exotic species. University ofCalifornia, Division of Agricultural Sciences, California, pp 363.

Deputy JC, Ming R, Ma H, Liu Z, Fitch MMM, Wang M, ... Stiles JI (2002). Molecular markers for sex determination in papaya (Carica papaya L.). Theoretical and Applied Genetics 106(1):107-111.

Doyle JJ, Doyle JL (1990). Isolation of plant DNA from fresh tissue. Focus 12(13):39-40.

Doyle J, Ferguson L (1998). Breeding persistent figs with Calimyrna quality. Acta Horticulturae 480:259-261.

Ejaz M, Iqbal M, Naeemullah M, Ahmed I, Shahzad A, Masood MS, Ali GM (2015). Validation and use ofDNA markers for sex determination in papaya (Caricapapaya). Pakistan Journal of Botany 47(3):1051-1059.

FAOSTAT (2013). Food and Agriculture Organization of the United Nation Statistics for 2013. Retrieved 2019 January 17 from http://www.fao.org/faostat/en/\#rankings/countries_by_commodity.

Francia E, Tacconi G, Crosatti C, Barabaschi D, Bulgarelli D, Dall'Aglio E, Vale G (2005). Marker assisted selection in crop plants. Plant Cell, Tissue and Organ Culture 82(3):317-342.

Heikrujam M, Sharma K, Kumar J, Agrawal V (2014). Generation and validation of unique male sex-specific sequence tagged sites (STS) marker from diverse genotypes of dioecious Jojoba-Simmondsia chinensis (Link) Schneider.Euphytica 199(3):363-372.

Hormaza JI, Dollo L, Polito VS (1994). Identification of a RAPD marker linked to sex determination in Pistacia vera using bulked segregant analysis. Theoretical and Applied Genetics 89(1):9-13.

Ince A, Karaca M (2011). Early determination of sex in jojoba plant by CAPS assay. The Journal of Agricultural Science 149(3):327-336.

Javid M, Rosewarne GM, Sudheesh S, Kant P, Leonforte A, Lombardi M, ... Kaur S (2015) Validation of molecular markers associated with boron tolerance, powdery mildew resistance and salinity tolerance in field peas. Frontiers in Plant Science 6:917.

Kafkas S, Khodaeiaminjan M, Güney M, Kafkas E (2015). Identification of sex-linked SNP markers using RAD sequencing suggests ZW/ZZ sex determination in Pistacia vera L. BMC Genomics 16(1):98.

Maryam, Jaskani MJ, Awan FS, Ahmad S, Khan IA (2016). Development of molecular method for sex identification in date palm (Phoenix dactylifera L.) plantlets using novel sex-linked microsatellite markers. 3 Biotech 6(1):22.

MaoY, Hou J, Chen X, Ni J, Zhao W, Wu L (2018). Identification of potential molecular markers for flower sex determination in Vernicia fordii. The Journal of Horticultural Science and Biotechnology 93(3):264-271.

Misırl A, Gülcan R, Topuz F (1998a). Determination of phenolic compounds in male and female figs. Acta Horticulturae 480:253-258.

Misırl A, Topuz F, Zeybekoğlu N (1998b). Research on variation of female and male figs in terms of leaf properties and stomatal distribution. Acta Horticulturae 480:129-132.

Mori K, Shirasawa K, Nogata H, Hirata C, Tashiro K, Habu T, ... Ikegami $\mathrm{H}$ (2017) Identification of RANI orthologue associated with sex determination through whole genome sequencing analysis in fig (Ficus carica L.). Nature Scientific Reports 7:41124.

Mutlu N, Ikten H, Gülsen O, Kocatas H, Aksoy U (2008). Association mapping for sex and fruit characterstics in Ficus carica. HortScience 43(4):1117-1117.

Parrish L, Hans P, Koelewijn HP Vandick PJ (2004). Identification of a male-specific AFLP marker in a functionally dioecious fig, Ficus fulva Reinw.exBl.(Moraceae). Sexual Plant Reproduction 17(1):17-22.

Sestras R, Pamfil D, Ardelean M, Botez C, Sestras A, Mitre I, ... Mihalte L (2009). Use of phenotypic and mas selection based on bulk segregant analysis to reveal the genetic variability induced by artificial hybridization in apple. Notulae Botanicae Horti Agrobotanici Cluj-Napoca 37(1):273-277.

Storey WB (1975). Figs. In: Janick J, Moore JN (eds) Advances in fruit breeding. Purdue University Press, West Lafayette, Indiana, pp 568-589.

Uragami A, Ueno R, Yamasaki A, Matsuo K, Yamaguchi T, Tokiwa H, ... Motoki S (2016). Productive differences between male and female plants in white Asparagus production using the rootstock-planting forcing culture technique. The Horticulture Journal 85(4):322-330.

Urasaki N, Tokumoto M, Tarora K, Ban Y, Kayano T, Tanaka H, ... Terauchi R (2002). A male and hermaphrodite specific RAPD marker for papaya (Carica papaya). Theoretical and Applied Genetics 104(23):281-285.

Yakubov B, Barazani O, Golan-Goldhirsh A (2005). Combination of SCAR primers and touchdown-PCR for sex identification in Pistacia vera L. ScientiaHorticulturae 103(4):473-478.

Zhang Q, Liu C, Liu Y, Van Buren R, Yao X, Zhong C, Huang H (2015). High-density interspecific genetic maps of kiwifruit and the identification of sex-specific markers. DNA Research 22(5):367-375.

Zheng J, Zhu M (2006). Isolation and sequence analysis of the sox-1, -2, -3 homologs in Trionyx sinensis and Alligator sinensis having temperaturedependent sex determination. Biochemical Genetics 44(3-4):98-109. 
Ikten H and Yilmaz Y et al / Not Bot Horti Agrobo, 2019, 47(3):867-871

Annexes

Supplementary Table 1. List of female and male fig genotypes

\begin{tabular}{|c|c|c|c|c|}
\hline Species & Genotype No & $\underline{\text { Variety/accession name and code }}$ & $\underline{\text { Sexuality }}$ & Sampling location \\
\hline & 1 & 3107 & Female & Fig Research Institute, Aydın,Turkey \\
\hline & 2 & 712 Siyah incir & Female & Fig Research Institute, Aydın,Turkey \\
\hline & 3 & 705 K.formu & Female & Fig Research Institute, Aydın,Turkey \\
\hline & 4 & 708 Darpak & Female & Fig Research Institute, Aydın,Turkey \\
\hline & 5 & 710 Ekși incir & Female & Fig Research Institute, Aydın,Turkey \\
\hline & 6 & 251 Dereköy & Female & Fig Research Institute, Aydın,Turkey \\
\hline & 7 & 215 Midilli & Female & Fig Research Institute, Aydın,Turkey \\
\hline & 8 & 252 Löp inciri & Female & Fig Research Institute, Aydın,Turkey \\
\hline & 9 & 219 & Female & Fig Research Institute, Aydın,Turkey \\
\hline & 10 & 228 İpek inciri & Female & Fig Research Institute, Aydın,Turkey \\
\hline & 11 & 245 Sarı Yemiş & Female & Fig Research Institute, Aydın,Turkey \\
\hline & 12 & 401 Mor özer & Female & Fig Research Institute, Aydın,Turkey \\
\hline & 13 & 538 Kabak inciri & Female & Fig Research Institute, Aydın,Turkey \\
\hline & 14 & 221 Yeşil incir & Female & Fig Research Institute, Aydın,Turkey \\
\hline & 15 & 537 Kara incir & Female & Fig Research Institute, Aydın,Turkey \\
\hline & 16 & Kizilay2 & Male & Fig Research Institute, Aydın,Turkey \\
\hline & 17 & Körpe ilek & Male & Fig Research Institute, Aydın,Turkey \\
\hline & 18 & Mor ilek & Male & Fig Research Institute, Aydın,Turkey \\
\hline & 19 & Afyoncu & Male & Fig Research Institute, Aydın,Turkey \\
\hline & 20 & Adalı & Male & Fig Research Institute, Aydın, Turkey \\
\hline & 21 & Gabalı & Male & Fig Research Institute, Aydın,Turkey \\
\hline & 22 & Ayardolduran & Male & Fig Research Institute, Aydın,Turkey \\
\hline & 23 & Siyah ilek & Male & Fig Research Institute, Aydın,Turkey \\
\hline & 24 & Ömerbeylikaba & Male & Fig Research Institute, Aydın,Turkey \\
\hline & 25 & 230 Siyah & Female & Fig Research Institute, Aydın,Turkey \\
\hline & 26 & 525 Ak incir-1 & Female & Fig Research Institute, Aydın,Turkey \\
\hline & 27 & 505 Kara sultani & Female & Fig Research Institute, Aydın,Turkey \\
\hline & 28 & 241 Gök bardak & Female & Fig Research Institute, Aydın,Turkey \\
\hline & 29 & 3304 & Female & Fig Research Institute, Aydın,Turkey \\
\hline & 30 & 704 Yabani f. & Female & Fig Research Institute, Aydın,Turkey \\
\hline & 31 & 227 Yediveren & Female & Fig Research Institute, Aydın,Turkey \\
\hline & 32 & 515 Tabak inciri & Female & Fig Research Institute, Aydın,Turkey \\
\hline & 33 & 232 Kocayemiş & Female & Fig Research Institute, Aydın, Turkey \\
\hline & 34 & 533 Agarsak & Female & Fig Research Institute, Aydın,Turkey \\
\hline & 35 & 701 Yabani-Mor & Female & Fig Research Institute, Aydn,Turkey \\
\hline & 36 & 542 Siyah Bakele & Female & Fig Research Institute, Aydın,Turkey \\
\hline \multirow[t]{37}{*}{ Ficus carica } & 37 & 236 Bardak & Female & Fig Research Institute, Aydın,Turkey \\
\hline & 38 & 254 Midilli & Female & Fig Research Institute, Aydın,Turkey \\
\hline & 39 & Dilbi & Female & Fig Research Institute, Aydın,Turkey \\
\hline & 40 & Bozdogankaba & Male & Fig Research Institute, Aydın,Turkey \\
\hline & 41 & Elma ilek & Male & Fig Research Institute, Aydın,Turkey \\
\hline & 42 & Bostanlı & Male & Fig Research Institute, Aydın,Turkey \\
\hline & 43 & Kara ilek & Male & Fig Research Institute, Aydın,Turkey \\
\hline & 44 & Şişek ileği & Male & Fig Research Institute, Aydın,Turkey \\
\hline & 45 & Kuyucak & Male & Fig Research Institute, Aydın,Turkey \\
\hline & 46 & Damarlı & Male & Fig Research Institute, Aydın,Turkey \\
\hline & 47 & Haci mestan & Male & Fig Research Institute, Aydın,Turkey \\
\hline & 48 & Kizlayl & Male & Fig Research Institute, Aydın,Turkey \\
\hline & 49 & 235 Yediveren & Female & Fig Research Institute, Aydın,Turkey \\
\hline & 50 & 512 İstanbul inciri & Female & Fig Research Institute, Aydın,Turkey \\
\hline & 51 & 404 Kış Hayri & Female & Fig Research Institute, Aydın,Turkey \\
\hline & 52 & 255 Siyah & Female & Fig Research Institute, Aydın,Turkey \\
\hline & 53 & 250 Yediveren & Female & Fig Research Institute, Aydın,Turkey \\
\hline & 54 & 706 Çilci & Female & Fig Research Institute, Aydın,Turkey \\
\hline & 55 & 403 Sultani & Female & Fig Research Institute, Aydın,Turkey \\
\hline & 56 & 534 Sarı incir & Female & Fig Research Institute, Aydın,Turkey \\
\hline & 57 & 3111 & Female & Fig Research Institute, Aydın,Turkey \\
\hline & 58 & 702 Yabanif. & Female & Fig Research Institute, Aydm,Turkey \\
\hline & 59 & Zapi & Female & Fig Research Institute, Aydın,Turkey \\
\hline & 60 & 201 İstanbul inciri & Female & Fig Research Institute, Aydın,Turkey \\
\hline & 61 & 209 Mor incir & Female & Fig Research Institute, Aydın,Turkey \\
\hline & 62 & 3110 & Female & Fig Research Institute, Aydın,Turkey \\
\hline & 63 & 239 İsyemez & Female & Fig Research Institute, Aydın,Turkey \\
\hline & 64 & Bardakçı & Male & Fig Research Institute, Aydın,Turkey \\
\hline & 65 & Kibrislı & Male & Fig Research Institute, Aydın,Turkey \\
\hline & 66 & Hacı Abdullah & Male & Fig Research Institute, Aydın,Turkey \\
\hline & 67 & Ak ilek & Male & Fig Research Institute, Aydın,Turkey \\
\hline & 68 & Seytanl & Male & Fig Research Institute, Aydın,Turkey \\
\hline & 69 & Ak erkekl & Male & Fig Research Institute, Aydın,Turkey \\
\hline & 70 & Yanakol & Male & Fig Research Institute, Aydın,Turkey \\
\hline & 71 & Frenk & Male & Fig Research Institute, Aydın,Turkey \\
\hline & 72 & Mistrkilek & Male & Fig Research Institute, Aydın,Turkey \\
\hline & 73 & 519 Şeker inciri & Female & Fig Research Institute, Aydın,Turkey \\
\hline
\end{tabular}


Ikten H and Yilmaz Y et al / Not Bot Horti Agrobo, 2019, 47(3):867-871

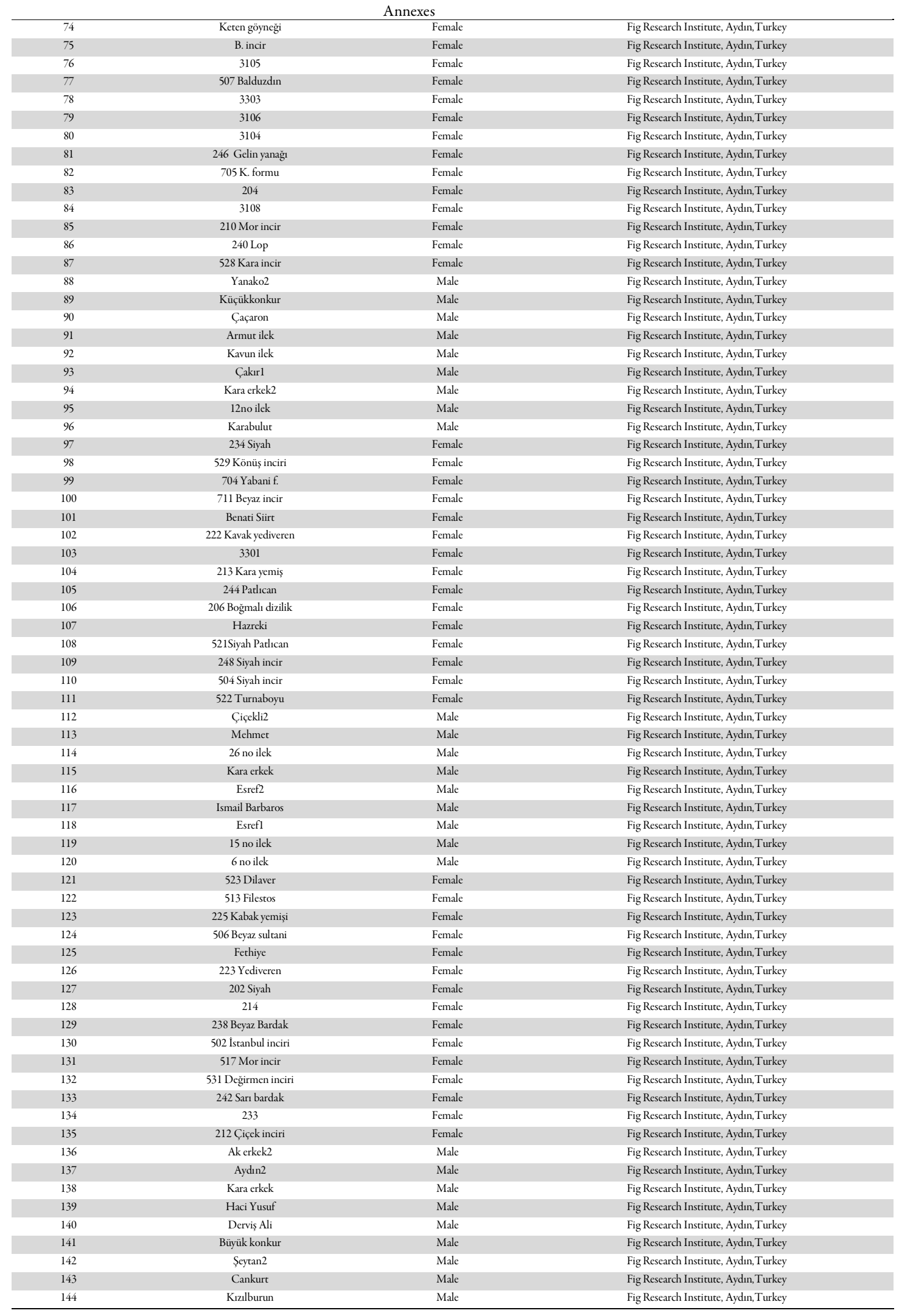

